University of Nebraska - Lincoln

DigitalCommons@University of Nebraska - Lincoln

USDA National Wildlife Research Center - Staff Publications
U.S. Department of Agriculture: Animal and Plant Health Inspection Service

May 2006

\title{
Evaluation of registered pesticides as repellents for reducing blackbird (Icteridae) damage to sunflower
}

G. M. Linz

USDA/APHIS/WS National Wildlife Research Center, george.m.linz@aphis.usda.gov

H.J. Homan

US Department of Agriculture, Wildlife Services (USDA/APHIS/WS), National Wildlife Research Center

A.A. Slowik

US Department of Agriculture, Wildlife Services (USDA/APHIS/WS), National Wildlife Research Center

L.B. Penry

US Department of Agriculture, Wildlife Services (USDA/APHIS/WS), National Wildlife Research Center

Follow this and additional works at: https://digitalcommons.unl.edu/icwdm_usdanwrc

Part of the Environmental Sciences Commons

Linz, G. M.; Homan, H.J.; Slowik, A.A.; and Penry, L.B., "Evaluation of registered pesticides as repellents for reducing blackbird (Icteridae) damage to sunflower" (2006). USDA National Wildlife Research Center Staff Publications. 422.

https://digitalcommons.unl.edu/icwdm_usdanwrc/422

This Article is brought to you for free and open access by the U.S. Department of Agriculture: Animal and Plant Health Inspection Service at DigitalCommons@University of Nebraska - Lincoln. It has been accepted for inclusion in USDA National Wildlife Research Center - Staff Publications by an authorized administrator of DigitalCommons@University of Nebraska - Lincoln. 


\title{
Evaluation of registered pesticides as repellents for reducing blackbird (Icteridae) damage to sunflower
}

\author{
G.M. Linz*, H.J. Homan, A.A. Slowik, L.B. Penry \\ US Department of Agriculture, Wildlife Services (USDA/APHIS/WS), National Wildlife Research Center, 2110 Miriam Circle, Suite B, \\ Bismarck, ND 58501, USA
}

Received 31 March 2005; received in revised form 7 November 2005; accepted 16 November 2005

\begin{abstract}
Chemical feeding repellents applied to ripening sunflower might help reduce blackbird (Icteridae) damage, which is a chronic agricultural problem from seed formation to harvest. However, costs are high to develop and register new repellents for agricultural use. In 2003 and 2004, we evaluated feeding repellency of 8 pesticides registered by the Environmental Protection Agency for use in sunflower. Caged red-winged blackbirds (Agelaius phoeniceus) were fed unshelled sunflower seeds treated with the following pesticides: 5 pyrethroid insecticides, an organochlorine, an organophosphorus, and a fungicide. Compared to untreated reference groups, feeding rates were reduced for 4 of the 5 pyrethroid insecticides. Only the organophosphorus (chlorpyrifos), however, significantly decreased feeding rates. More research on repellency effects of this product in field efficacy trials is probably warranted based on the results of our cage experiments. Depending on timing of application, registered insecticides with blackbird feeding repellency could provide supplemental economic benefits to sunflower producers through dual purpose use.
\end{abstract}

(C) 2005 Elsevier Ltd. All rights reserved.

Keywords: Blackbirds; Insecticides; Repellents; Red-winged Blackbird; Sunflower

\section{Introduction}

In the Prairie Pothole Region of central North America, blackbirds (Icteridae) begin exploiting and damaging fields of commercial sunflower in mid-August (Linz and Hanzel, 1997). During this period, blackbirds undergo annual feather molt and begin pre-migratory fattening. Both demand large amounts of energy that can be met by eating calorie-rich seeds from developing heads of sunflower. The problem is further exacerbated by the birds' drive to congregate in roosting flocks that can contain 50,000-500,000 individuals (Linz et al., 2003). The flocks gravitate towards sunflower for nutrition because it is easily accessible and provides the most energy of the available food sources. Losses in sunflower production resulting from blackbird damage can be severe, especially during the first 3 weeks of seed maturation (Cummings et al., 1989). Defending against persistent and voracious

\footnotetext{
${ }^{*}$ Corresponding author. Tel.: $+7102504469 x 3$; fax: +7012504408 .

E-mail address: george.m.linz@aphis.usda.gov (G.M. Linz).
}

blackbird flocks is a costly endeavor to sunflower producers, both in time and money (Linz and Hanzel, 1997). No single method to reduce damage has been consistently effective, because blackbirds derive energy benefits from exploiting sunflower that probably exceed the costs producers are willing to spend on its defense.

The development of nonlethal repellents to reduce blackbird damage is a priority with the sunflower industry. Under certain conditions, repellents can be effective nonlethal feedings deterrents (Avery et al., 1997). It is generally accepted that the stronger the repellent characteristics (e.g., poor taste) the more likely birds will seek food elsewhere, especially if alternative foods and foraging sites are available (Dolbeer, 1990; Avery et al., 2001). The USDA Wildlife Services' National Wildlife Research Center has tested many compounds for bird repellency (Schafer et al., 1983; Mason and Clark, 1992; Avery, 2003). A few have shown promise and advanced beyond cage trials to large enclosure tests and field trials. In the 1970s field trials were carried out with methiocarb, an insecticide no longer registered for food uses, and 
carbaryl (Woronecki et al., 1981), which is still registered for use in sunflower. Both insecticides reduced the amount of bird activity and bird damage. The authors suspected, however, that neither product was a true bird repellent, and that the drop in blackbird activity was related to reductions in post-treatment insect populations. Regardless, carbaryl was again found to reduce blackbird activity on ripening rice after aerial application to control insects in Louisiana (Avery, 2003). No further research has been done, despite the promise of carbaryl as a blackbird repellent.

Over the last decade, activated charcoal (Mason and Clark, 1994, 1995), methyl anthranilate (Werner et al., 2005), anthraquinone (Avery et al., 2000a), and caffeine (Avery et al., 2005) have been studied for their potential as bird repellents for ripening grain crops. Only methyl anthranilate has been approved for use on food crops. No differences in blackbird damage were detected when sunflower fields and rice fields treated with methyl anthranilate were compared against adjacent placebo fields (Werner et al., 2005). Methyl anthranilate works by irritating the eyes, nostril, or mouth (Avery, 2003); a lack of treatment effect was probably due to the product's low concentration of active ingredient (Stevens and Clark, 1998). Anthraquinone had shown great potential for repellency in laboratory and large enclosure trials (Avery et al., 1998); however, it was not effective when used on fields of newly sprouted rice, perhaps the result of poor coverage from inadequate methods of application (Avery et al., 2000a, b). Other studies on anthraquinone have yielded contradictory results; for example, it repelled blackbirds from ripening rice in Louisiana but not from ripening wild rice in California (Avery, 2003; Avery et al., 2000a). In the latter case, the birds were nesting, roosting, and feeding in the test fields, and this may have mitigated the treatment effect. Caffeine is another repellent that has shown promise during cage trials, flight pen trials, and in field trials as a seed treatment (Avery et al., 2005). Trials on ripening crops, which often receive the most bird pressure, have not been conducted.

Sunflower growers have several registered pesticides available to them for managing insect and disease problems. We tested some of these pesticides for bird repellency. Adding additional uses to an existing pesticide registration often costs far less than the expenditures for registration of a new repellent for agricultural use. If a registered pesticide also were to provide feeding repellency, it would be a new damage management tool obtained at a relatively minimal developmental cost. A dual-use strategy that incorporates the pesticide's original use with the additional use as a blackbird feeding repellent saves not only on the costs of crop loss from blackbirds but also the costs incurred from defense against blackbird damage. A reduction in these costs can represent major savings to agriculture producers coping annually with blackbird damage to sunflower.

In fall 2003 and 2004, we used red-winged blackbirds (Agelaius phoeniceus) in caged feeding trials to look for bird repellency in 8 pesticides registered for use in sunflower. Our objective was to compare differences in feeding rates of birds fed unshelled sunflower seeds coated with labelrecommended rates of these pesticides.

\section{Methods}

\subsection{Experimental subjects}

Repellency tests on red-winged blackbirds were conducted during August and September 2003 and 2004. We mist-netted or decoy-trapped red-winged blackbirds near Bismarck, North Dakota, USA, and placed them in a roofed outdoor aviary in two holding cages $(2.4 \mathrm{~m} \times 2.4 \mathrm{~m} \times 2.4 \mathrm{~m})$. The birds were held at least 2 weeks before being used in repellency tests. During this time, they had free access to drinking and bathing water, grit, and a maintenance diet made up of a mixture of rice, finely chopped sunflower, cracked corn, and millet. Test birds were removed from their holding cages 4 days before treatment and isolated in individual cages (dimensions $61 \mathrm{~cm}$ length $\times 36 \mathrm{~cm}$ height $\times 41 \mathrm{~cm}$ width). Five subjects were used per treatment. In 2003, we used 3 females and 2 males per treatment; whereas, in 2004 we used only males. The pretreatment routine consisted of removal of maintenance food at $0730 \mathrm{~h}$ and placement of $30 \mathrm{~g}$ of untreated sunflower seeds $1 \mathrm{~h}$ later. Seeds were provided in clear glass bowls $(8.0 \mathrm{~cm}$ diameter $\times 3.2 \mathrm{~cm}$ high) placed by the cage doors. The bowls were removed $3 \mathrm{~h}$ later and clean cups of fresh maintenance food and water were provided. Seed consumption was measured to the nearest $0.1 \mathrm{~g}$. Spillage was captured and accounted for by placing the seed bowls in larger clear plastic cups $(12 \mathrm{~cm}$ diameter $\times 7.5 \mathrm{~cm}$ height). To determine daily mass changes of seeds from air moisture absorption, $30 \mathrm{~g}$ of seeds were placed in glass cups $(n=5)$ in vacant cages near the active test cages.

After the pretreatment period, test subjects were assigned to either the pesticide- or untreated-reference group based on their average sunflower seed consumption during the pretreatment period. The bird with the highest average was randomly assigned to a treatment group, the next highest to the opposing group, until all subjects were systematically assigned to either a pesticide- or reference-treatment. This helped to ensure that each treatment group would potentially eat the same amount. A 3-day break occurred before the 4-day treatment period. During this time, daily provisions of maintenance food mix and water were provided. The routine for the treatment period was the same as described above for the pretreatment period. This procedure was used for each pesticide treatment, with sunflower being presented at $0830 \mathrm{~h}$ for $3 \mathrm{~h}$ over 4 consecutive days.

\subsection{Bait preparation}

We weighed whole oilseed sunflower seeds in 1-kg batches. Each batch was stirred in a clean electric mixer 
with the appropriate amounts of water and pesticide (Table 1). For experimental purposes, the volume of pesticide solution applied to seed batches was based on the assumption that, in an aerial field application of the pesticide, all would settle on the seeds. Of course, this is not possible because much of the spray would land on plant vegetation. This assumption, however, allowed us to standardize the application. To determine volume per treatment batch, we used average field production (626 kg/ha) in North Dakota from 1997 to 2001 (NDASS, 2002). The pesticide solution was slowly added to the seeds and mixed until the achene surfaces appeared dry. The treated seeds were then air-dried and stored in an airconditioned laboratory in darkness.

\subsection{Statistical analyses}

We used descriptive statistics (mean and SE) to illustrate differences in feeding rates between pesticide-treated and reference groups. We tested the null hypothesis of no treatment effects with a repeated measures analysis of variance (Proc Mixed; Littell et al., 1996), with food consumption $\left(\mathrm{g} \mathrm{bird}^{-1}\right)$ as the dependent variable, birdwithin-treatment as a random effect, and day as the repeated measure. We used the treatment-by-day interac-

Table 1

Eight EPA-registered pesticides tested for feeding repellency on individually caged red-winged blackbirds during August and September 2003-2004 in North Dakota

\begin{tabular}{|c|c|c|c|}
\hline Active ingredient & $\begin{array}{l}\text { Product } \\
\text { formulation }\end{array}$ & Chemical class & Rate $(\mathrm{ml} / \mathrm{kg})$ \\
\hline Chlorpyrifos & Lorsban- $4 \mathrm{E}^{\circledR \mathrm{a}}$ & Organophosphorus & $\begin{array}{l}1.13 \\
0.56 \\
0.28 \\
0.14\end{array}$ \\
\hline Esfenvalerate & Asana $\mathrm{XL}^{\circledR \mathrm{b}}$ & Pyrethroid & 0.46 \\
\hline $\begin{array}{l}\text { Lambda- } \\
\text { cyhalothrin }\end{array}$ & Warrior $\mathrm{T}^{\circledR \mathrm{C}}$ & Pyrethroid & 0.18 \\
\hline Cyfluthrin & Baythroid $2^{\circledR \mathrm{d}}$ & Pyrethroid & 0.13 \\
\hline Tralomethrin & Scout X-TRA ${ }^{\circledR e}$ & Pyrethroid & 0.12 \\
\hline $\begin{array}{l}\text { Zeta- } \\
\text { cypermethrin }\end{array}$ & MustangMAX ${ }^{\mathrm{TM} f}$ & Pyrethroid & 0.19 \\
\hline Endosulfan & Endosulfan $3 \mathrm{EC}^{\circledR \mathrm{R}}$ & Organochlorine & 2.00 \\
\hline Boscalid & Endura $^{\circledR h}$ & $\begin{array}{l}\text { Carboxamide aka } \\
\text { anilide }\end{array}$ & 0.41 \\
\hline
\end{tabular}

The amount of chemical $(\mathrm{ml})$ applied to $1 \mathrm{~kg}$ of sunflower achenes was determined by calculating the maximum amount of chemical that could settle on the seeds in a sunflower field yielding $626 \mathrm{~kg} / \mathrm{ha}$ (North Dakota's average field production).

${ }^{\mathrm{a}}$ Lorsban- $4 \mathrm{E}^{\circledR}$ is a registered trademark of Dow AgroSciences LLC.

${ }^{\mathrm{b}}$ Asana XL ${ }^{\circledR}$ is a registered trademark of DuPont Chemical Company.

${ }^{\mathrm{c}}$ Warrior $\mathrm{T}^{\mathbb{R}}$ is a registered trademark of Syngenta Crop Protection, Inc.

${ }^{\mathrm{d}}$ Baythroid $2^{\circledR}$ is a registered trademark of Bayer Crop Protection.

${ }^{\text {e}}$ Scout X-TRA ${ }^{\circledR}$ is a registered trademark of Adventis CG.

${ }^{\mathrm{f}}$ MustangMAX ${ }^{\mathrm{TM}}$ is a registered trademark of FMC Corporation.

${ }^{\mathrm{g}}$ Endosulfan $3 \mathrm{EC}^{\circledR}$ is a registered trademark of Gowan Company.

${ }^{\mathrm{h}}$ Endura ${ }^{\circledR}$ is a registered trademark of BASF Corporation. tion to examine differences in food consumption between treatments over the duration of the 4-day experiments. LSMEANS was used to separate means when the over-all treatment effect was significant at $p \leqslant 0.05$.

\section{Results}

In October 2003, 4 insecticides (chlorpyrifos, cyfluthrin, esfenvalerate, and tralomethrin) were tested for repellency traits at full-label rates recommended by the product's manufacture (Table 1). Overall, mean consumption $\left(\mathrm{g} \mathrm{bird}^{-1}\right)$ differed greatly among treatments $\left(F_{4,20}=\right.$ 14.54; $p<0.001$ ), with the group fed chlorpyrifos-treated sunflower eating less than the other 3 pesticide groups and the reference group (Fig. 1). The chlorpyrifos test birds showed a $58 \%$ decline in feeding rate from day 1 $\left(1.7 \mathrm{~g} \mathrm{bird}^{-1}\right)$ to day 4 but did not show any particular physiological distress during this time. The interaction of treatment $\times$ day was not significant $\left(F_{12,60}=1.08\right.$; $p=0.394)$. The group presented chlorpyrifos-treated seeds ate $1.2 \mathrm{~g}(\mathrm{SE}=0.19)$ bird $^{-1}$ (Fig. 1), a reduction of $81 \%$ compared to the untreated reference group $\left(\bar{x}=6.3 \mathrm{~g} \mathrm{bird}^{-1}, \mathrm{SE}=0.36, p=<0.001\right)$. This rate also was significantly less than all other treatment groups $(p=<0.001)$, including cyfluthrin $\left(\bar{x}=6.5 \mathrm{~g} \mathrm{bird}^{-1}\right.$, $\mathrm{SE}=0.44), \quad$ esfenvalerate $\left(\bar{x}=5.1 \mathrm{~g} \mathrm{bird}^{-1}, \mathrm{SE}=0.35\right)$, and tralomethrin $\left(\bar{x}=4.7 \mathrm{~g} \mathrm{bird}^{-1}, \mathrm{SE}=0.28\right)$. Although esfenvalerate and tralomethrin caused reductions in feeding rates compared to the reference birds, these were much smaller $(\leqslant 25 \%)$ than the chlorpyrifos treatment. Cyfluthrin had no demonstrable repellent effect in this experiment.

Encouraged by the reduced feeding rate observed for the chlorpyrifos treatment at full-label, we proceeded to test

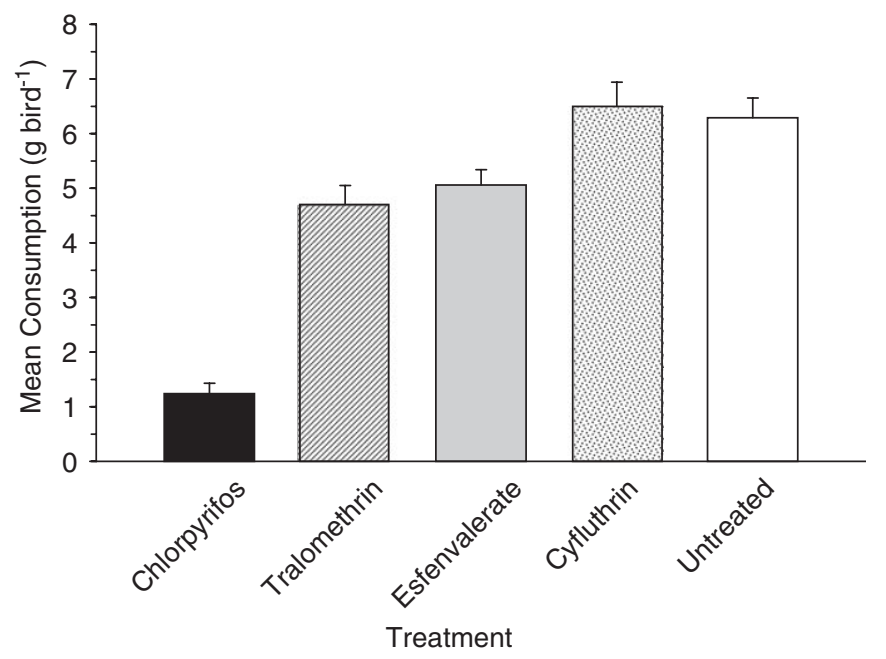

Fig. 1. Consumption of unshelled sunflower (g) by individually caged male $(n=2)$ and female $(n=3)$ red-winged blackbirds after treatment with full-label rates of chlorpyrifos, tralomethrin, esfenvalerate, and cyfluthrin. Each bird was given $30 \mathrm{~g}$ of sunflower for $3 \mathrm{~h}$ on each of 4 treatment days. Capped vertical bars denote $1 \mathrm{SE}$. 
this pesticide at $50 \%, 25 \%$, and $12.5 \%$ of full-label rate (Fig. 2); also included in this second set of experiments was the pesticide, lambda-cyhalothrin. Overall, mean consumption was significantly different among treatments $\left(F_{4,20}=5.54 ; p=0.004\right)$. The interaction of treatment $\times$ day was not significant $\left(F_{12,60}=0.65 ; p=0.792\right)$. The chlorpyrifos treatment at $50 \%$ of full-label rate $(0.57 \mathrm{ml} /$ $\mathrm{kg}$ ) caused the birds to eat $58 \%$ less than the reference birds $(p=0.002)$, which ate $10.1 \mathrm{~g} \mathrm{bird}^{-1}(\mathrm{SE}=1.0)$. All other treatment groups, including lambda-cyhalothrin, had

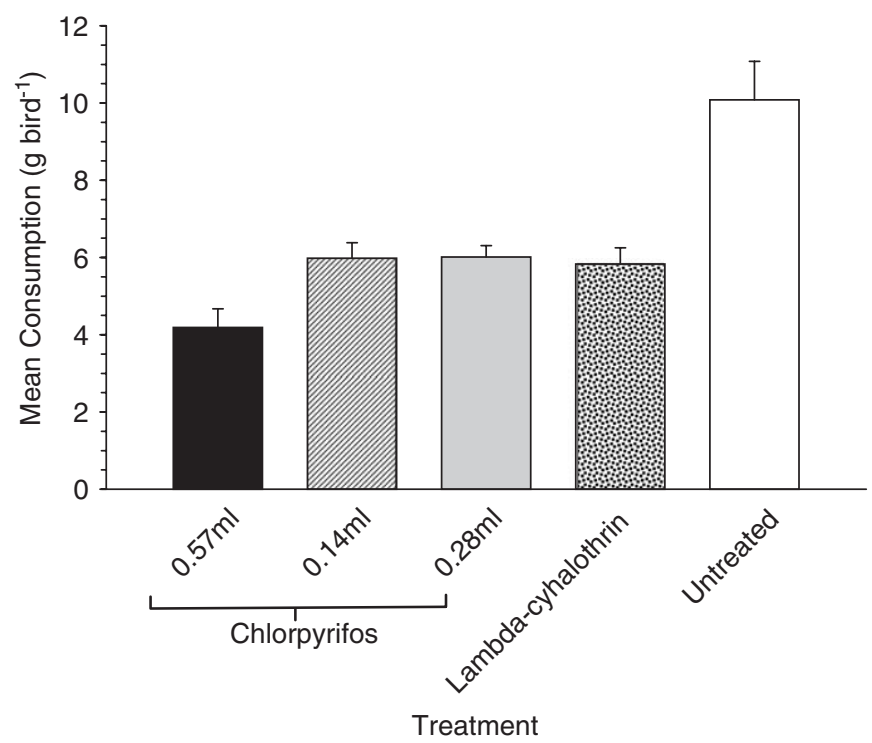

Fig. 2. Consumption of unshelled sunflower (g) by individually caged male $(n=2)$ and female $(n=3)$ red-winged blackbirds after treatment with 3 concentrations of chlorpyrifos beneath full-label rate, and lambdacyhalothrin at full-label rate. Each bird was given $30 \mathrm{~g}$ of sunflower for $3 \mathrm{~h}$ on each of 4 treatment days. Capped vertical bars denote $1 \mathrm{SE}$.

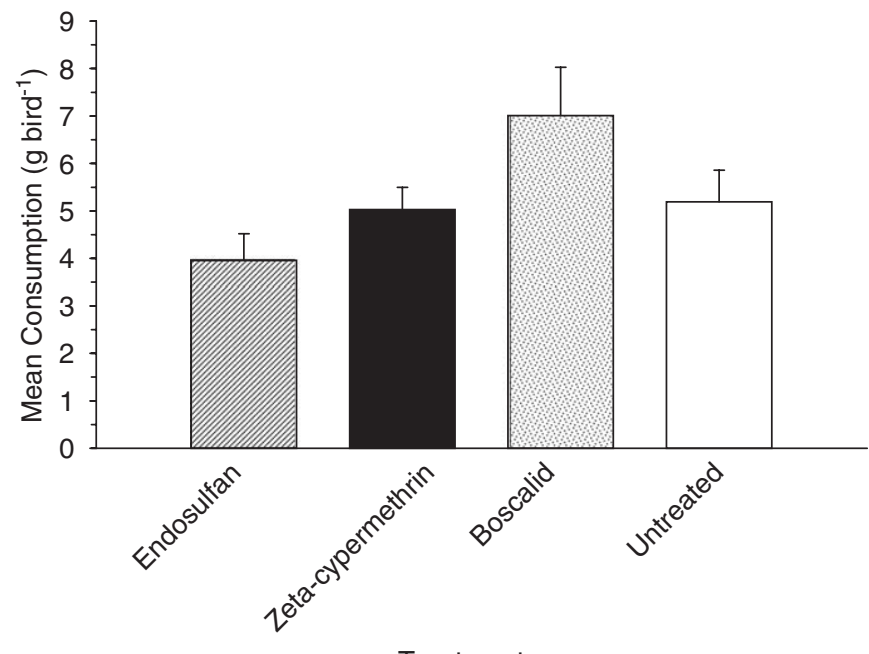

Treatment

Fig. 3. Consumption of unshelled sunflower ( $g$ ) by individually caged male $(n=5)$ red-winged blackbirds after treatment with zeta-cypermethrin, endosulfan and boscalid at full-label rates. Each bird was given $30 \mathrm{~g}$ of sunflower for $3 \mathrm{~h}$ on each of 4 treatment days. Capped vertical bars denote $1 \mathrm{SE}$. marginally insignificant reductions $(p=0.051-0.071)$ of about $40 \%\left(\bar{x}=6.0 \mathrm{~g} \mathrm{bird}^{-1}, \mathrm{SE}=0.41 \mathrm{~g}\right)$ compared to the reference group. The higher feeding rates in the second feeding trial were likely due to shorter daylight hours and colder temperatures in late October.

In October 2004, we tested 2 more insecticides, zetacypermethrin and endosulfan. Additionally, we tested boscalid, a fungicide registered for sunflower. All were tested at full label rates. Overall, mean consumption did not differ among treatments $\left(F_{3,16}=0.760 ; p=0.530\right)$ and the interaction of treatment $x$ day was not significant $\left(F_{9,48}=1.74 ; p=0.106\right)$. Oddly, the birds assigned to the boscalid group ate $26 \%$ more sunflower $\left(\bar{x}=7.0 \mathrm{~g} \mathrm{bird}^{-1}\right.$, $\mathrm{SE}=1.02)$ than did birds in the reference group $\left(\bar{x}=5.2 \mathrm{~g} \mathrm{bird}^{-1}, \mathrm{SE}=0.67\right)($ Fig. 3).

\section{Discussion}

The goal of the initial screening of the 8 pesticides was to discover if any of them had potential as bird repellents. Thus, when deciding on the pesticide concentration with which to coat the seeds, we allowed the untenable assumption that the face of the sunflower head (i.e., seed area) would receive the entire application. Although the assumption was unrealistic, because in an aerial field application the sunflower canopy would receive the majority of the spray, it served our purpose of including several candidates in the study at once and quickly culling those with low field potential.

Compared to the reference treatment, we found that 5 out of the 7 pesticides reduced feeding rates. This is an important finding because the birds did not have alternative foods available during the 3 -h test and had not eaten for at least $12 \mathrm{~h}$ because of the length of the dark cycle in North Dakota during the experimental period. Only the chlorpyrifos $\quad[(\mathrm{O}, \mathrm{O}$-diethyl-O-(3,5,6-richloro-2-pyridinyl) phosphorothioate)] formulation was sufficiently potent as a feeding repellent to warrant further experimentation. In fact, chlorpyrifos even at the $50 \%$ application rate outperformed the other pesticides at full-label strength.

Chlorpyrifos is an insecticide, acaricide, and miticide that is used on a broad group of food and feed crops. It is used on ripening sunflower at up to 3.51/ha per application to control cutworms, weevils, moths, and beetles. However, about $50 \%$ of the annual 4.5 million $\mathrm{kg}$ of chlorpyrifos used in the US is used on corn. Chlorpyrifos is derived from phosphoric and phosphonic acid and thus is hydrolyzed in water. The half-life of chlorpyrifos is about $7 \mathrm{~d}$ in seawater and $53 \mathrm{~d}$ in distilled water. Other factors affect the half-life, such as water $\mathrm{pH}$, temperature, sunlight, and concentrations of metal cations (Odenkirchen and Eisler, 1988). If chlorpyrifos demonstrates an ability to repel blackbirds in field trials, we recommend that studies be conducted to determine half-life under climatic conditions commonly encountered in late August and September, the peak period of blackbird damage in North Dakota. 
Classified as an organophosphate, chlorpyrifos is a cholinesterase inhibitor. Risk analyses suggest that a single application of chlorpyrifos can pose a risk to small mammals, birds, fish, and aquatic invertebrates (Odenkirchen and Eisler, 1988). These risks are somewhat mitigated by label restrictions that limit applications in sunflower to every 7-10 days with a maximum 10.41/ha/ season, along with a 42-day waiting period between the last application and harvest. The waiting period may not be a problem, since sunflower is often not harvested until months after the peak damage period.

\section{Management implications}

Product registration for a new chemical bird repellent for use in agricultural crops would require a voluminous amount of data by the EPA. The costs of research and development associated with new registrations could be avoided to some degree if bird repellency traits were found in one or more existing EPA-registered pesticides. It is likely, however, that a new formulation, incorporating a particular active ingredient, might be needed to avoid patent issues. Even so, the EPA requires much less data for new use registrations with a proven active ingredient in most cases. In turn, sunflower growers would receive a large cost saving by getting a dual use from the product.

Future research should include experiments with chlorpyrifos beyond cage studies. We should determine if chlorpyrifos needs to be applied directly to the seeds (as was done in these trials) or if aerial spraying of a field will achieve similar results in repellency. Moreover, it is possible that the repellency we observed in Lorsban-4E might not be due solely to the active ingredient, chlorpyrifos, which makes up about $45 \%$ of this product's formulation (Dow AgroSciences LLC, Indianapolis, Indiana, USA). The other $55 \%$ consists of co-formulants, including aromatic petroleum distillates, which have strong odors. More research will be needed to discover the contribution that these additives may have in repellency.

A thorough cost and benefit would need to be conducted prior to registering a new use for chlorpyrifos. We will continue our research on the efficacy and environmental effects of chlorpyrifos and other candidate bird repellents. Lastly, providing alternative food plots, currently being researched by scientists from the National Wildlife Research Center and North Dakota State University (Linz et al., 2004), might enhance the efficacy of any repellent or scare device and should be included in integrated damage management strategies (Dolbeer, 1990; Avery et al., 2001).

\section{Acknowledgements}

We thank R. Engeman for statistical advice. This study was funded by the US Department of Agriculture, North Dakota/South Dakota Wildlife Services, Bismarck, ND, and the National Sunflower Association, Bismarck, ND.
The US Department of Agriculture and the National Sunflower Association do not endorse the use of any of the tested pesticides as bird repellents.

\section{References}

Avery, M.L., 2003. Avian repellents. In: Plimmer, J.R., Gammon, D.W., Ragsdale, N.N. (Eds.), Encyclopedia of Agrochemicals. Wiley, New York, pp. 1-8.

Avery, M.L., Humphrey, J.S., Decker, D.G., 1997. Feeding deterrence of anthraquinone, anthracene, and anthrone to rice-eating birds. J. Wildlife Manage. 61, 1359-1365.

Avery, M.L., Humphrey, J.S., Primus, T.M., Decker, D.G., McGrane, A.P., 1998. Anthraquinone protects rice seed from birds. Crop Prot. 17, 225-230.

Avery, M.L., Whisson, D.A., Marcum, D.B., 2000a. Responses of blackbirds to mature wild rice treated with flight control bird repellent. In: Proceedings of Vertebrate Pest Conference, vol. 19, pp. 26-30.

Avery, M.L., Tillman, E.A., Humphrey, J.S., Cummings, J.L., York, D.L., Davis Jr., J.E., 2000b. Evaluation of overspraying as an alternative to seed treatment for application of flight control bird repellent to newly planted rice. Crop Prot. 19, 225-230.

Avery, M.L., Tillman, E.A., Laukert, C.C., 2001. Evaluation of chemical repellents for reducing crop damage by dickcissels in Venezuela. Int. J. Pest Manage. 47, 311-314.

Avery, M.L., Werner, S.J., Cummings, J.L., Humphrey, J.S., Milleson, M.P., Carlson, J.C., Primus, T.M., Goodall, M.J., 2005. Caffeine for reducing bird damage to newly seeded rice. Crop Prot. 24, 651-657.

Cummings, J.L., Guarino, J.L., Knittle, C.E., 1989. Chronology of blackbird damage to sunflower. Wildlife Soc. Bull. 17, 50-52.

Dolbeer, R.A., 1990. Ornithology and integrated pest management: redwinged blackbirds Agelaius phoeniceus and corn. Wildlife Soc. Bull. 132, 309-322.

Linz, G.M., Hanzel, J.J., 1997. Birds and sunflower. In: Schneider, A. (Ed.), Sunflower Science and Technology. American Society of Agronomy, Madison, WI, pp. 381-394.

Linz, G.M., Sawin, R.A., Lutman, M.W., Homan, H.J., Penry, L.B., Bleier, W.J., 2003. Characteristics of spring and fall blackbird roosts in the northern Great Plains. In: Proceedings of the Wildlife Damage Management Conference, vol. 10, pp. 220-228.

Linz, G.M., Schaaf, D.A., Mastrangelo, P., Homan, H.J., Penry, L.B., Bleier, W.J., 2004. Wildlife conservation sunflower plots as a dualpurpose wildlife management strategy. In: Proceedings of the Vertebrate Pest Conference, vol. 21, pp. 291-294.

Littell, R.C., Milliken, G.A., Stroup, W.W., Russel, D., 1996. SAS ${ }^{\circledR}$ System for Mixed Models. SAS Institute Inc., Cary, NC, USA.

Mason, J.R., Clark, L., 1992. Nonlethal repellents: the development of cost-effective, practical solutions to agricultural and industrial problems. In: Proceedings of the Vertebrate Pest Conference, vol. 15, pp. 115-129.

Mason, J.R., Clark, L., 1994. Use of activated charcoal and other particulate substances as feed additives to suppress bird feeding. Crop Prot. 13, 219-224.

Mason, J.R., Clark, L., 1995. Evaluation of methyl anthranilate and activated charcoal as snow goose grazing deterrents. Crop Prot. 14, 467-469.

North Dakota Agricultural Statistics Service, 2002. North Dakota agricultural statistics 2001. North Dakota State University, Fargo, Agricultural Statistics No. 72, 112pp.

Odenkirchen, E.W., Eisler, R., 1988. Chlorpyrifos hazards to fish, wildlife, and invertebrates: a synoptic review. US Fish Wildlife Serv. Biol. Rep. $85,34 \mathrm{pp}$.

Schafer Jr., E.W., Bowles Jr., W.A., Hurlbut, J., 1983. The acute oral toxicity, repellency, and hazard potential of 998 chemicals to one or more species of wild and domestic birds. Arch. Environ. Contam. Toxicol. 12, 355-382. 
Stevens, G.R., Clark, L., 1998. Bird repellents: development of avianspecific tear gases for resolution of human-wildlife conflicts. Int. Biodeterior. Biodegrad. 42, 153-160.

Werner, S.J., Homan, H.J., Avery, M.L., Linz, G.M., Tillman, E., Slowik, T.A., Byrd, R.W., Primus, T.M., Goodall, M.J., 2005. Evaluation of
Bird Shield ${ }^{\mathrm{TM}}$ as a blackbird repellent in ripening rice and sunflower fields. Wildlife Soc. Bull. 32, 870-880.

Woronecki, P.P., Dolbeer, R.A., Stehn, R.A., 1981. Response of blackbirds to mesural and sevin applications on sweet corn. J. Wildlife Manage. 45, 693-701. 